\title{
Comparison of Fatty Acid Profiling and RBC Membrane Stabilization Activity of Seabuckthorn (Hippophae rhamnoides and Hippophae salicifolia) Seed Oil
}

\author{
Suchita Dubey ${ }^{1 *}$, M.V. Ramana ${ }^{1}$, Anuradha Mishra ${ }^{2}$
}

\section{Suchita Dubey ${ }^{1 *}$, M.V. Ramana', Anuradha Mishra² \\ 'Amity Institute of Pharmacy, Amity University Uttar Pradesh, Lucknow Campus, Uttar Pradesh, INDIA. ${ }^{2}$ Faculty of Pharmacy, Integral University, Lucknow, Uttar Pradesh, INDIA.}

\section{Correspondence}

\section{Suchita Dubey,}

Amity Institute of Pharmacy, Amity University Uttar Pradesh, Lucknow Campus, Uttar Pradesh, INDIA

Ph. No- +91-9161830884/ +91-9015918818

E-mail: suchita.kanpur@gmail.com

\section{History}

- Submission Date: 02-02-17;

- Review completed: 07-03-17;

- Accepted Date: 13-03-17

DOI : 10.5530/pj.2017.3.56

Article Available online http://www.phcogj.com/v9/i3

\section{Copyright}

(C) 2017 Phcog.Net. This is an openaccess article distributed under the terms of the Creative Commons Attribution 4.0 International license.

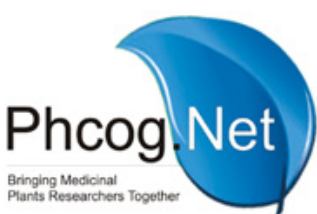

\begin{abstract}
Background: Seabuckthorn (SBT) is one of the most important plants of higher altitude in India and China. SBT seed oil is rich in Poly Unsaturated Fatty Acid (PUFA) which is present in a peculiar ratio capable of combating inflammation. Objective: To compare the physicochemical characteristics, fatty acid profiling and Red Blood Cell (RBC) membrane stabilization activity between two species of SBT seed oil; Hippophae rhamnoides (HR) and Hippophae salicifolia (HS) collected from Ladakh and Sikkim, India, respectively. Materials and Methods: GC-MS analysis was performed and effect of SBT seed oil was evaluated against heat and hypotonicity induced haemolysis of RBC. Protein denaturation assay was also conducted to check its probable role in chronic inflammation. Results: GC-MS analysis confirmed the presence of PUFA viz. Alpha linolenic acid (ALA) and Linoleic acid (LA) in SBT seed oil. Both significantly $(p<0.05)$ inhibited heat and hypotonicity induced membrane destabilization in a concentration dependant manner. Maximum percentage inhibition of protein denaturation was observed at $3.6 \mathrm{\mu g} / \mathrm{ml}$ after incubation period of 4 hours. Conclusion: HR and HS have been proved to inhibit membrane destabilization with almost equal efficacy. Their efficacy against heat induced protein denaturation indicates that they may be useful in prevention and/or treatment of chronic inflammation as well. These findings may be attributed to the presence of PUFA. This study has contributed in establishing some preliminary evidence about PUFAs being the mainstay of their anti-inflammatory efficacy. However, in vivo studies are required to further validate the results of this study.

Key words: RBC Membrane Stabilization, Protein Denaturation, Sea buckthorn Seed Oil, GC-MS, in vitro.
\end{abstract}

\section{INTRODUCTION}

Seabuckthorn (SBT) is a parasol term used for all species of genus Hippophae. Two of the most prominent Indian species of this plant are Hippophae rhamnoides (HR) and Hippophae salicifolia (HS), henceforth, collectively referred to as SBT. SBT is among the medicinal plants with the widest spectra of use for various indications including cough, diarrhoea, menstrual, and stomach disorders. ${ }^{1}$ It has been used in Eastern traditional medicine for centuries, especially higher altitude regions. In the Chinese Pharmacopeia, sea buckthorn berries are prescribed for relieving cough and for promoting digestion and blood circulation. A considerable number of studies on leaves and berries have been carried out in China, Russia, and other Asian countries, but are in native languages, therefore have limited accessibility. Moreover, SBT seed oil still remains unexplored in many contexts. ${ }^{2}$

Previous studies have revealed presence of considerable amount of $\omega-3$ and $\omega-6$ fatty acids namely Alpha Linolenic Acid (ALA) and Oleic Acid (OA) in HR and HS seed oil ${ }^{3}$ which are precursors of other Poly Unsaturated Fatty Acids (PUFAs) like arachidonic acid and eicosapentenoic acid (EPA). ${ }^{4}$ The proinflammatory eicosanoids, prostaglandin E2 and leukotriene $\mathrm{B} 4$, are derived from the $\mathrm{n}-6$ fatty acid, arachidonic acid (AA), which is maintained at high cellular concentrations by increased $n-6$ and decreased n-3 PUFA content of the modern western diet. HR and HS seed oil contains the 18-carbon n-3 fatty acid, ALA, which can be converted after ingestion to the 20-carbon n-3 fatty acid, EPA. EPA is believed to act as a competitive inhibitor of AA conversion to prostaglandin E2 and leukotriene B4, thereby, decreasing the synthesis of one or both of these eicosanoids. Similar to the effect of $n-3$ fatty acids, inclusion of the 20-carbon n- 9 fatty acid, eicosatrienoic acid ${ }^{5}$ and $\mathrm{OA}^{6}$ in the diet also results in decreased synthesis of LTB4.

Treatment of inflammation includes extensive use of non-steroidal anti-inflammatory agents (NSAIDs). ${ }^{\text {? }}$ However, their use makes the patients more vulnerable to gastrointestinal and liver toxicities. ${ }^{8}$ Therefore, new anti-inflammatory drugs having alternative mechanisms are being searched as substitutes to NSAIDs. ${ }^{9}$

Inflammation is a complicated biological response of vascular tissues to external detrimental stimuli and can either be acute or chronic. At the onset of an inflammatory process, the cells undergo activation and release inflammatory mediators such as histamine and serotonin. ${ }^{10}$ These mediators collectively cause elevated vasodilatation and permeability of 
blood vessels leading to increased blood flow, exudation of plasma proteins and fluids, and migration of leukocytes, mainly neutrophils, outside the blood vessels into the injured tissues. ${ }^{11}$ Acute inflammation is characterized by marked vascular changes, including vasodilatation and increased capillary permeability which are induced by the actions of the various inflammatory mediators. Hence, membrane stabilization was taken up as a measure of the anti-inflammatory property of SBT seed oil.

Chronic inflammatory conditions may involve protein denaturation. ${ }^{12}$ Saso et al., 1999 demonstrated that presence of PUFA such as AA, LA and ALA etc. inhibit heat induced protein denaturation ${ }^{13,14}$ Hence, it becomes essential to assess the level of protein denaturation in presence of SBT seed oil to understand its potential in chronic inflammatory conditions.

\section{MATERIALS AND METHODS}

\section{Plant material}

HR and HS seeds were obtained from Leh, Ladakh and Sikkim, India, respectively. The seeds were authenticated at National Botanical Research Institute, Lucknow and voucher sample was deposited.

\section{Extraction of oil}

Seeds were washed, air dried, crushed and extracted in petroleum ether $\left(40-60^{\circ} \mathrm{C}\right)$ for 7 days using a soxhlet apparatus. Petroleum ether was evaporated from the extract and the oil was filtered to clarity. The oil was stored at room temperature in amber coloured airtight bottle. To avoid oxidation, the oil was purged with nitrogen and was filled to the brim of the bottle so that there was no head space. The yield of HR and HS was $6.50 \%$ and $10.80 \% \mathrm{v} / \mathrm{w}$, respectively with reference to dried seeds. The density of the HR and HS was $0.90 \mathrm{mg} / \mathrm{ml}$ and $0.916 \mathrm{~g} / \mathrm{ml}$, respectively.

\section{Physico-chemical analysis of SBT Seed Oil} Gas Chromatography Mass Spectroscopy (GC-MS) of SBT Seed Oil

GCMS analysis was carried out by using GCMS-TQ8030 (SHIMADZU); column: RXI-5 sil MS, dimension ( $30 \mathrm{M} \times 0.25 \mathrm{~mm} \times 0.25 \mu \mathrm{m})$; with column temperature $90^{\circ} \mathrm{C}$ and injection temperature $290^{\circ} \mathrm{C}$. About $25 \mathrm{mg}$ of oil samples were weighed separately, treated with $2 \mathrm{~mL}$ of methanolic $\mathrm{H}_{2} \mathrm{SO}_{4}(2.5 \%)$ and the mixture was incubated at $80^{\circ} \mathrm{C}$ for $15 \mathrm{~min}$. To this mixture, $1 \mathrm{~mL}$ of aqueous $\mathrm{NaCl}$ solution $(0.9 \%)$ was added and cooled at room temperature then $2 \mathrm{~mL}$ hexane was added. After a gentle shake, it was allowed to stand for about 15 minutes, hexane layer was separated and used for GCMS analysis.

\section{Drugs and Chemicals}

Aspirin was procured from Himedia Laboratories, Mumbai, India. Dimethyl Sulphoxide (DMSO) was purchased from SD fine Chemicals Ltd., Mumbai, India. All the chemicals used were of analytical grade.

\section{Preparation of sample}

$0.1 \mathrm{ml}$ of SBT seed oil was dissolved in $1 \mathrm{ml}$ of tween 80 and incubated for $10 \mathrm{~min}$ in a regulated water bath at $37^{\circ} \mathrm{C}$. It was then purged with nitrogen in a round bottom flask and sample thus left at the bottom was dissolved in phosphate buffer solution ( $\mathrm{pH}-7.4)$. Subsequent serial dilutions of $0.9,1.8,2.7,3.6,4.5 \mathrm{mg} / \mathrm{ml}$ were made for each of the sample.

\section{Blood Sample}

Fresh whole blood $(3 \mathrm{ml})$ was collected intravenously from healthy human volunteers into heparinised tubes to prevent coagulation.

\section{Preparation of erythrocyte suspension}

Fresh whole blood $(3 \mathrm{ml})$ collected from healthy volunteer into heparinised tubes was centrifuged at $3000 \mathrm{rpm}$ for 10 minutes. A volume of normal saline equivalent to that of the supernatant was used to dissolve the red blood pellets. The volume of the dissolved red blood pellets obtained was measured and reconstituted as a $40 \% \mathrm{v} / \mathrm{v}$ suspension with isotonic buffer solution (10 mM sodium phosphate buffer, $\mathrm{pH}$ 7.4). The buffer solution contained $0.2 \mathrm{~g}$ of $\mathrm{NaH}_{2} \mathrm{PO}_{4}, 1.15 \mathrm{~g}$ of $\mathrm{Na}_{2} \mathrm{HPO}_{4}$ and $9 \mathrm{~g}$ of $\mathrm{NaCl}$ in $1 \mathrm{ltr}$ of distilled water. The reconstituted red blood cells (re-suspended supernatant) were used as such.

\section{Assay of membrane stabilization}

The effect of the SBT seed oil on haemolysis of Red blood cell (RBC) induced by heat and distilled water was evaluated using the method of Shinde et al. ${ }^{15}$ with some modifications.

\section{Heat induced haemolysis}

Samples of SBT seed oil prepared as described above were dissolved in isotonic phosphate buffer solution. A set of 5 centrifuge tubes containing $5 \mathrm{ml}$ graded doses of the samples $(0.9,1.8,2.7,3.6,4.5 \mathrm{mg} / \mathrm{ml})$ were arranged in quadruplicate sets (4 sets per dose). Two sets of control tubes contained $5 \mathrm{ml}$ of the vehicle and $5 \mathrm{ml}$ of $1 \mathrm{mg} / \mathrm{ml}$ of aspirin respectively. $\mathrm{RBC}$ suspension $(0.1 \mathrm{ml})$ was added to each of the tubes and mixed gently. A pair of the tubes was incubated at $54^{\circ} \mathrm{C}$ for $20 \mathrm{~min}$ in a regulated water bath. The other pair was maintained at $-10^{\circ} \mathrm{C}$ in a freezer for $20 \mathrm{~min}$. Afterwards, the tubes were centrifuged at $10000 \mathrm{rpm}$ for $3 \mathrm{~min}$ and the haemoglobin content of the supernatant was estimated using SHIMADZU 1800 spectrophotometer at $540 \mathrm{~nm}$. The percent inhibition of haemolysis by the extract was calculated thus:

$$
\% \text { Inhibition of Haemolysis }=1-\left(\mathrm{OD}_{2}-\mathrm{OD}_{1} / \mathrm{OD}_{3}-\mathrm{OD}_{1}\right)^{*} 100^{15}
$$

Where OD1 = absorbance of test sample unheated

OD2 = absorbance of test sample heated

OD3 = absorbance of control sample heated.

\section{Hypotonicity induced haemolysis}

Samples of the extract used in this test were dissolved in distilled water (hypotonic solution). The hypotonic solution $(5 \mathrm{ml})$ containing graded doses of the extracts $(0.9,1.8,2.7,3.6,4.5 \mathrm{mg} / \mathrm{ml})$ were put into duplicate pairs (per dose) of the centrifuge tubes. Isotonic solution $(5 \mathrm{ml})$ containing graded doses of the extracts $(0.9,1.8,2.7,3.6,4.5 \mathrm{mg} / \mathrm{ml})$ were also put into duplicate pairs (per dose) of the centrifuge tubes. Control tubes contained $5 \mathrm{ml}$ of the vehicle (distilled water) and $5 \mathrm{ml}$ of $1 \mathrm{mg} / \mathrm{ml}$ of aspirin respectively. Erythrocyte suspension $(0.1 \mathrm{ml})$ was added to each of the tubes and mixed gently. The mixtures were incubated for 1 hour at room temperature $\left(37^{\circ} \mathrm{C}\right)$, and afterwards, centrifuged for 3 minutes at 10,000 rpm. Absorbance (OD) of the haemoglobin content of the supernatant was estimated at $540 \mathrm{~nm}$ using SHIMADZU UV 1800 spectrophotometer.

The percentage haemolysis was calculated by assuming the haemolysis produced in the presence of distilled water as $100 \%$. The percent inhibition of haemolysis by the extract was calculated thus:

$$
\% \text { Inhibition of Haemolysis }=\left(\mathrm{OD}_{1}-\mathrm{OD}_{2 /} \mathrm{OD}_{1}\right)^{\star} 100^{15}
$$

Where $\mathrm{OD}_{1}=$ absorbance of control sample

$\mathrm{OD}_{2}=$ absorbance of test sample

\section{Inhibition of protein denaturation}

Methodology was adopted from Nargund et al, 1993 with slight modifications. ${ }^{16}$ The reaction mixture $(5 \mathrm{~mL})$ consisted of $0.2 \mathrm{~mL}$ of egg albumin (from fresh hen's egg), $2.8 \mathrm{~mL}$ of phosphate buffered saline ( $\mathrm{pH}$ 6.4) and $2 \mathrm{~mL}$ of varying concentrations of $\mathrm{HR}$ and $\mathrm{HS}$ so that final concentrations become $0.9,1.8,2.7,3.6,4.5 \mathrm{mg} / \mathrm{ml}$. Similar volume of doubledistilled water served as control. Then the mixtures were incubated at $\left(37^{\circ} \mathrm{C} \pm 2\right)$ in a BOD incubator (Thermotech, NISCO) for $15 \mathrm{~min}$ and then heated at $70^{\circ} \mathrm{C}$ for $5 \mathrm{~min}$. After cooling, their absorbance was measured at $660 \mathrm{~nm}$ (SHIMADZU, UV 1800) by using vehicle as blank. 
Acetyl salicylic Acid at the final concentration of $(0.9,1.8,2.7,3.6,4.5$ $\mathrm{mg} / \mathrm{ml}$ ) was used as reference drug and treated similarly for determination of absorbance.

The percentage inhibition of protein denaturation was calculated by using the following formula:

$$
\% \text { Inhibition of inhibition }=\left(\mathrm{OD}_{1}-\mathrm{OD}_{2 /} \mathrm{OD}_{1}\right)^{\star} 100^{16}
$$

Where $\mathrm{OD}_{1}=$ absorbance of control sample

$\mathrm{OD}_{2}=$ absorbance of test sample

\section{Statistical analysis}

Statistical analysis was carried out using Graph Pad Prism 5.0 (Graph Pad Software, San Diego, CA). All results were expressed as mean \pm SD. The data was analyzed by one-way ANOVA followed by Bonferroni multiple comparison test and statistically significant data was accepted when $\mathrm{P}<0.05$. Paired $\mathrm{t}$-test was calculated between treated groups and data was considered to be statistically significant ( $\mathrm{P}$ - value $<0.05$ ).

\section{RESULTS}

The density, specific gravity, colour, iodine value, acid value, and saponification value of both the seed oil samples were measured. The results obtained were in confirmation with the previous reports by Sabir et al, $2005 .{ }^{14}$ The GCMS analysis of both the oil samples revealed presence of palmitoleic acid (6.72\%), eicosanoic acid (11.18\%), and LA (39.71\%) in HR. It was also found rich in ALA (Figure S1). Around $34.93 \%$ of 9-Octadecenoic acid, methyl ester, (E), OA, was found in HS (Figure S2). ALA in HS was also detectable in significant quantity with molecular weight 278 (Figure S3). Peak for ALA was obtained as M and M-35 since it was detected in chloride form in GC-MS. Gamma linolenic acid (GLA) was also detected, but in insignificant quantities (Figure S4 and Figure S5). Both the samples were found to be rich in saturated fatty acids as well as PUFA. In preliminary phytochemical analysis, HR was found to contain more tocopherols and carotenoids than HS. Other important constituents such as alkaloids, glycosides, flavonoids and phenols were not detected in both the oil samples.

The result of the membrane stabilization assay of HR and HS exhibit its potential to stabilize the cell membrane and thus aiding in attenuation of inflammation. Heat induced destabilization of RBC membrane was inhibited in a concentration dependent manner in both the samples (Table 1). The inhibition of HR was found to be $79.20 \%$ at $4.5 \mu \mathrm{g} / \mathrm{ml}$ concentration which was significant in comparison to aspirin $(80 \%)$ $(\mathrm{P}=0.003)$. Similarly, HS exhibited a significant inhibition of $75 \%$ in comparison to aspirin ( $80 \%)(\mathrm{P}=0.04)$. Figure 1 delineates concentration dependent increase in percentage inhibition of heat induced membrane destabilization.

Both, HR and HS exhibited maximum RBC stabilization of $84.78 \%$ $(\mathrm{P}=0.002)$ and $71.73 \%(\mathrm{P}<0.01)$ at $4.5 \mu \mathrm{g} / \mathrm{ml}$ in hypotonicity induced medium (Table 2). The anti-inflammatory activity of HR and HS against heat and hypotonicity induced membrane destabilization was found to be dependent on concentration but attained a saturation level in subsequent last two highest concentrations of $3.6 \mu \mathrm{g} / \mathrm{ml}$ and $4.5 \mu \mathrm{g} / \mathrm{ml}$. Figure 2 outlines concentration dependent increase in percentage inhibition of hemolysis induced membrane destabilization at the optimum concentration of $2.7 \mu \mathrm{g} / \mathrm{ml}$ and $3.6 \mu \mathrm{g} / \mathrm{ml}$ of HR and HS.

The inhibition of protein denaturation by HR and HS showed different patterns in reference to concentration and time. The study revealed that inhibition of protein denaturation of both HR and HS was associated with concentration and time. The percentage inhibition was directly proportional to increase in concentration. However, it was observed that, with time, the percentage inhibition of protein denaturation increases for first 4 hours and then decreases for subsequent 8 hours. At the advent of $12^{\text {th }}$ hour, the value of percentage inhibition went minimal. HR and HS exhibited maximum protein denaturation percentage inhibition of $62.41 \%(\mathrm{P}<0.03)$ and $63.04 \%(\mathrm{P}<0.04)$ at $3.6 \mu \mathrm{g} / \mathrm{ml}$ after incubation period of 4 hours. A considerable decrease in the value of percentage inhibition of up to $13.41 \%$ and $13.05 \%$ was observed when calculated after 8 hours. Figure 3 depicts that HR and HS exhibit time and concentration dependent change in percentage inhibition of protein denaturation. A steep inverted V shaped graph reveals that the percentage inhibition sharply increases with concentration as well as time, and then decreases.

\section{DISCUSSION}

Our study revealed considerable presence of LA and ALA which is precursor of other PUFAs like arachidonic acid and eicosapentenoic acid. ${ }^{4}$ Our results are also in corroboration with the study of Yang and Kallio, 2001. ${ }^{17}$ The presence of 9-Octadecenoic acid, methyl ester, (E), $\mathrm{OA}$, was found in HS in higher concentrations.

In humans, $\alpha$-linolenic and linoleic acids are precursors of other longchain n-3 and n- 6 fatty acids. They in turn are precursors for eicosanoids and other local hormones modulating inflammation and secretory and cardiovascular functions. As a not always accurate generalization, the effects of n-6 derived eicosanoids are commonly described as pro-inflammatory, whereas the effects of n-3 derived eicosanoids are considered anti-inflammatory or neutral. ${ }^{18-20}$ Conversions of the 18-carbon n-3/n- 6 fatty acids to their derivatives of longer chains and a higher degree of unsaturation involve a series of desaturases and elongases shared by the $\mathrm{n}-3$ and $\mathrm{n}-6$-families. Competition between the fatty acids of n-3 and n- 6 families for the same enzymes in these conversions makes the $n-3 / n-6$ ratio in the diet important. Additionally, the $n-3$ fatty acids may also affect the expression of inflammatory genes and cytokine production. ${ }^{18,19}$

Western/Modern diets commonly contain n-6 and n-3 fatty acids in the ratio of 10:1 or higher, which is undesirably high according to most authorities. The current recommendations for the $n-6 / n-3$ ratio in the diet vary from less than $4: 1$ to $10: 1{ }^{21}$ The SBT seed oil contains $n-6 / n-3$ in the ratio close to $1: 1^{22}$ which may prove to be a contributor in substantiating anti-inflammatory activity.

Inflammation has been known to deteriorate the usual physiological process gradually. From sickness to respiratory, CVS, CNS ailments to cancer, inflammation has been known to trigger all. It is a physiological reaction to a disrupted tissue homeostasis. ${ }^{23}$ In acute inflammation, it is a tissue-destroying process that involves the recruitment of blood-derived products, such as plasma proteins, fluid, and leukocytes, into perturbed tissue. This migration is facilitated by changes in the local vasculature that lead to vasodilation, increased vascular permeability, and increased blood flow. ${ }^{24}$

Vitality of cells depends on the integrity of the cell membranes. RBCs exposure to injurious substances such as hypotonic medium may cause rupture of the membrane accompanied by haemolysis and oxidation of haemoglobin. Inflammation implies breakdown of lysosomes which release their component enzymes responsible for a variety of disorders. ${ }^{25}$ Also, membrane-stabilizing interactions of macrolides with neutrophils have been postulated to counteract the pro-inflammatory and prooxidative activity of several bioactive lipids which have been implicated in the pathogenesis in case of bronchial asthma. ${ }^{26}$ Taking indirect evidences from the above study, it was thought that HR and HS seed oil may stabilize the RBC membrane which is analogous to leukocyte membrane.

Membrane destabilization has also been known to recommend/support the release of eicosanoids. ${ }^{27}$ Since RBC membranes are similar to lysosomal 
membrane ${ }^{28}$ the inhibition of hypotonicity and heat induced red blood cell membrane lysis was taken as a measure of the mechanism of antiinflammatory activity of HR and HS. The haemolytic effect of hypotonic solution is related to excessive accumulation of fluid within the cell resulting in the rupturing of its membrane.

Membrane stabilization leads to the prevention of leakage of serum protein and fluids into the tissues during a period of increased permeability caused by inflammatory mediators. Such injury to RBC membrane will further render the cell more susceptible to secondary damage through free radical-induced lipid peroxidation. Fatty acid micelles scavenge superoxide in an unsaturation-dependent manner. It was proposed by Richard et al. 2008 that the series of PUFA might act as indirect antioxidant in vascular endothelial cells, hence, diminishing inflammation. ${ }^{29}$ The antioxidant potential of HR and HS was studied by Ting et al., 2010. Their find-

Table 1: *Percentage inhibition of heat induced membrane destabilization by SBT (HR and HS)

\begin{tabular}{|c|c|c|c|c|}
\hline \multirow[t]{2}{*}{ Treatment } & \multirow[t]{2}{*}{$\begin{array}{l}\text { Concentration } \\
(\mu \mathrm{g} / \mathrm{ml})\end{array}$} & $\begin{array}{c}\text { Absorbance } \\
\text { (Mean } \pm \text { SEM) }\end{array}$ & \multirow[t]{2}{*}{ Cold Sol } & \multirow[t]{2}{*}{$\begin{array}{l}\text { Percentage } \\
\text { inhibition }\end{array}$} \\
\hline & & Heated Sol & & \\
\hline \multirow[t]{5}{*}{ Control } & 4.5 & $0.36 \pm 0.04$ & \multirow{5}{*}{-} & \multirow{5}{*}{ - } \\
\hline & 3.6 & $0.48 \pm 0.01$ & & \\
\hline & 2.7 & $0.41 \pm 0.07$ & & \\
\hline & 1.8 & $0.45 \pm 0.009$ & & \\
\hline & 0.9 & $0.45 \pm 0.03$ & & \\
\hline \multirow{5}{*}{$\begin{array}{l}\text { Standard } \\
\text { (Aspirin) }\end{array}$} & 4.5 & $0.16 \pm 0.002$ & $0.11 \pm 0.001$ & 80 \\
\hline & 3.6 & $0.20 \pm 0.034$ & $0.14 \pm 0.003$ & 77 \\
\hline & 2.7 & $0.23 \pm 0.05$ & $0.16 \pm 0.24$ & 72 \\
\hline & 1.8 & $0.29 \pm 0.003$ & $0.16 \pm 0.013$ & 35 \\
\hline & 0.9 & $0.43 \pm 0.02$ & $0.34 \pm 0.05$ & 36 \\
\hline \multirow[t]{5}{*}{ HR } & 4.5 & $0.17 \pm 0.03$ & $0.12 \pm 0.0007$ & 79.2 \\
\hline & 3.6 & $0.36 \pm 0.02$ & $0.27 \pm 0.004$ & 58 \\
\hline & 2.7 & $0.61 \pm 0.001$ & $0.49 \pm 0.0$ & 46 \\
\hline & 1.8 & $0.69 \pm 0.06$ & $0.61 \pm 0.0$ & 13 \\
\hline & 0.9 & $0.76 \pm 0.04$ & $0.73 \pm 0.0$ & 12.5 \\
\hline \multirow[t]{5}{*}{ HS } & 4.5 & $0.12 \pm 0.05$ & $0.04 \pm 0.0$ & 75 \\
\hline & 3.6 & $0.27 \pm 0.008$ & $0.14 \pm 0.0$ & 62 \\
\hline & 2.7 & $0.34 \pm 0.003$ & $0.29 \pm 0.0$ & 59 \\
\hline & 1.8 & $0.40 \pm 0.005$ & $0.28 \pm 0.0$ & 30 \\
\hline & 0.9 & $0.40 \pm 0.02$ & $0.29 \pm 0.0$ & 32 \\
\hline
\end{tabular}

${ }^{*} \mathrm{p}$ value of $<0.05$ was considered to be significant

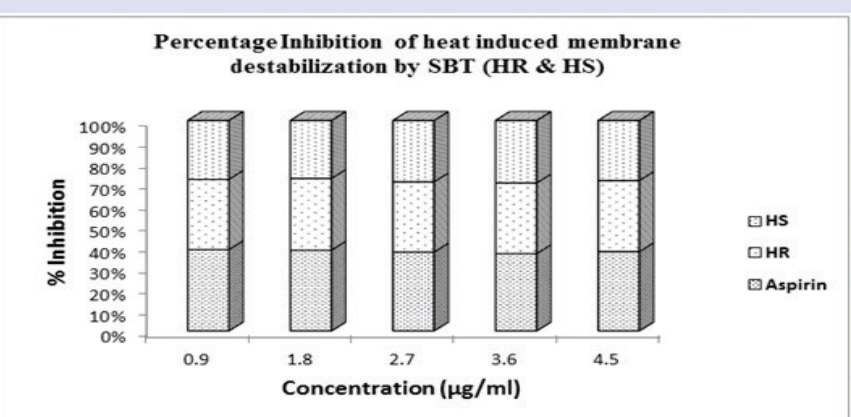

Figure 1: Percentage Inhibition of heat induced membrane destabilization by Seabuckthorn (Hippophae rhamnoides \& Hippophae salicifolia) ings suggested that a concentration dependent increase is observed in free radical scavenging, DPPH scavenging and inhibition of lipid per-oxidation activities of $\mathrm{HR}$ and HS. ${ }^{30}$ They attributed its natural antioxidant potential to presence of PUFA, tocopherols and carotenoids. Our findings are in concordance with their study.

In anti-denaturation assay, the denaturation of egg albumin is induced by heat. Heat-denatured proteins are equally effective as native proteins in inducing delayed hypersensitivity. ${ }^{31}$ Thus, anti-denaturation assay is the convenient method to check the anti-inflammatory activity against chronic inflammation. The inhibition of protein denaturation by HR and HS showed different patterns in reference to concentration and time. The study revealed that inhibition of protein denaturation of both HR and HS was associated with concentration and time. The percentage inhibition was directly proportional to increase in concentration. However, it was Table 2: *Percentage inhibition of hypotonicity induced membrane destabilization by SBT (HR and HS)

\begin{tabular}{|c|c|c|c|}
\hline Treatment & $\begin{array}{l}\text { Concentration } \\
(\mu \mathrm{g} / \mathrm{ml})\end{array}$ & $\begin{array}{c}\text { Mean absorbance } \\
\text { (Mean } \pm \text { SEM) }\end{array}$ & $\%$ inhibition \\
\hline \multirow[t]{5}{*}{ Normal } & 0.9 & $0.71 \pm 0.003$ & \\
\hline & 1.8 & $0.64 \pm 0.020$ & \\
\hline & 2.7 & $0.60 \pm 0.054$ & \\
\hline & 3.6 & $0.53 \pm 0.056$ & \\
\hline & 4.5 & $0.46 \pm 0.039$ & \\
\hline \multirow{5}{*}{$\begin{array}{l}\text { Standard } \\
\text { (Aspirin) }\end{array}$} & 0.9 & $0.13 \pm 0.021$ & 81.69 \\
\hline & 1.8 & $0.11 \pm 0.009$ & 82.81 \\
\hline & 2.7 & $0.06 \pm 0.038$ & 90 \\
\hline & 3.6 & $0.06 \pm 0.051$ & 88.67 \\
\hline & 4.5 & $0.02 \pm 0.030$ & 95.65 \\
\hline \multirow[t]{5}{*}{ HR } & 0.9 & $0.21 \pm 0.070$ & 70.42 \\
\hline & 1.8 & $0.17 \pm 0.061$ & 73.43 \\
\hline & 2.7 & $0.12 \pm 0.036$ & 80 \\
\hline & 3.6 & $0.10 \pm 0.005$ & 81.11 \\
\hline & 4.5 & $0.07 \pm 0.171$ & 84.78 \\
\hline \multirow[t]{5}{*}{ HS } & 0.9 & $0.29 \pm 0.154$ & 59.15 \\
\hline & 1.8 & $0.26 \pm 0.165$ & 59.37 \\
\hline & 2.7 & $0.18 \pm 0.236$ & 70 \\
\hline & 3.6 & $0.15 \pm 0.04$ & 71.69 \\
\hline & 4.5 & $0.13 \pm 0.026$ & 71.73 \\
\hline
\end{tabular}

${ }^{*} \mathrm{p}$ value of $<0.05$ was considered to be significant.

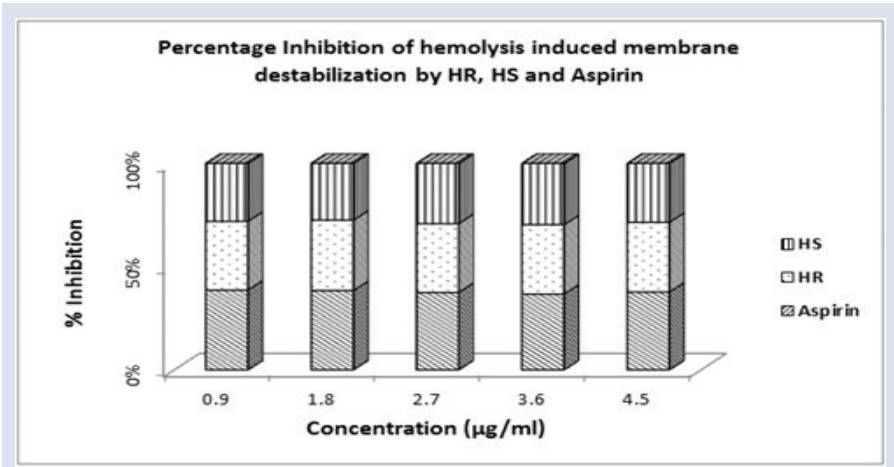

Figure 2: Percentage Inhibition of hemolysis induced membrane destabilization by (Hippohae rhamnoides, Hippophae salicifolia) 
Table 3: *Percentage inhibition of heat induced protein denaturation by SBT (HR and HS) at different time intervals

\begin{tabular}{|c|c|c|c|c|c|}
\hline \multirow[t]{2}{*}{ Group } & \multirow[t]{2}{*}{ Concentration $(\mu \mathrm{g} / \mathrm{ml})$} & 1 hours & 4 hours & 8 hours & 12 hours \\
\hline & & \multicolumn{4}{|c|}{ Percentage Inhibition } \\
\hline \multirow[t]{5}{*}{${ }^{* * \text { Standard (Aspirin) }}$} & 0.9 & 22.08 & 43.07 & 37.09 & 12.01 \\
\hline & 1.8 & 25.74 & 45.46 & 34.08 & 12.38 \\
\hline & 2.7 & 37.26 & 50.28 & 40.79 & 14.59 \\
\hline & 3.6 & 49.01 & 67.03 & 42.84 & 13.04 \\
\hline & 4.5 & 48.08 & 66.94 & 53.08 & 19.78 \\
\hline \multirow[t]{5}{*}{ HR } & 0.9 & 18.56 & 38.51 & 33.02 & 07.24 \\
\hline & 1.8 & 18.89 & 44.46 & 34.45 & 13.05 \\
\hline & 2.7 & 31.24 & 47.28 & 36.24 & 12.08 \\
\hline & 3.6 & 39.64 & 58.93 & 35.89 & 13.84 \\
\hline & 4.5 & 39.81 & 62.41 & 37.57 & 13.51 \\
\hline \multirow[t]{5}{*}{ HS } & 0.9 & 21.04 & 45.71 & 29.86 & 09.14 \\
\hline & 1.8 & 25.89 & 44.25 & 29.24 & 11.36 \\
\hline & 2.7 & 33.28 & 55.28 & 35.89 & 12.25 \\
\hline & 3.6 & 42.06 & 62.29 & 38.84 & 14.85 \\
\hline & 4.5 & 41.78 & 63.04 & 38.95 & 13.05 \\
\hline
\end{tabular}

${ }^{*} \mathrm{p}$ value of $<0.05$ was considered to be significant.

${ }^{* *} \mathrm{p}$ value of $<0.005$ was considered to be significant.

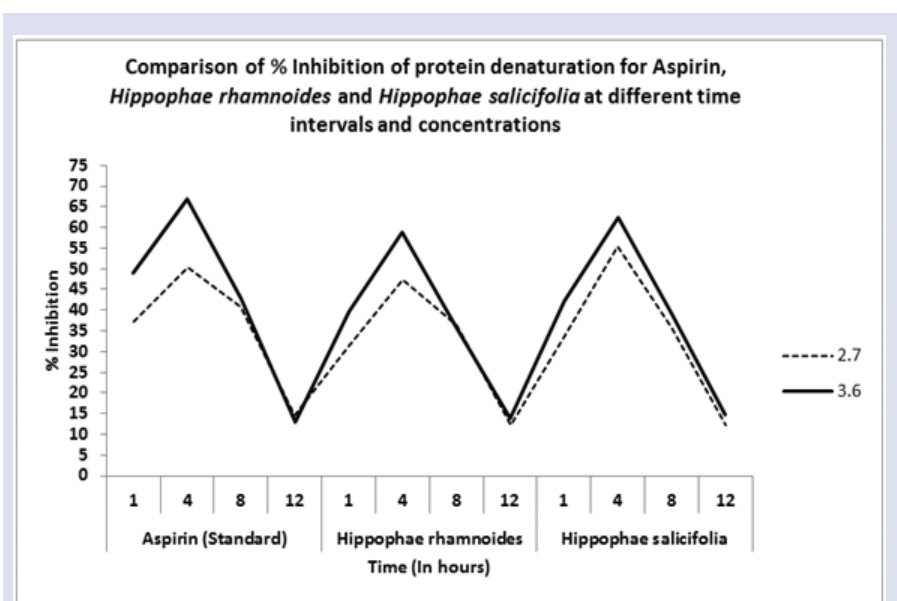

Figure 3: Comparison of \% Inhibition of protein denaturation for Aspirin, HR and $\mathrm{HS}$ at different time intervals and concentrations

observed that, with time, the percentage inhibition of protein denaturation increases for first 4 hours and then decreases for subsequent 8 hours. At the advent of $12^{\text {th }} \mathrm{h}$, the value of percentage inhibition went minimal and was statistically as well as clinically insignificant.

According to the results of the present study, the extract has shown considerable anti-inflammatory activity (Table 3). HR and HS are capable of controlling the production of auto antigen and thereby it inhibits the denaturation of proteins and its effect was compared with the standard drug Aspirin. The presence of oleic, caprylic, capric, lauric, myristic, palmitic, stearic, oleic, linoleic, arachidonic, eicosapentaenoic and docosahexaenoic acids lead to an effective inhibition of protein denaturation. ${ }^{13}$ Majority of these are present in HR and HS seed oil.

\section{CONCLUSION}

HR and HS have been proved to inhibit membrane destabilization with almost equal efficacy. Their efficacy against heat induced protein dena- turation indicates that they may be useful in prevention and/or treatment of chronic inflammation as well. These findings may be attributed to the presence of PUFA. This study has contributed in establishing some preliminary evidence about PUFAs being the mainstay of their antiinflammatory efficacy. However, in vivo studies are required to further validate the results of this study.

\section{ACKNOWLEDGEMENT}

The authors are grateful to Dr. Ashok K. Chauhan, Hon'-ble Founder President, Amity University Uttar Pradesh, for providing required facilities for successful completion of this work.

\section{CONFLICT OF INTEREST}

None

\section{ABBREVIATION USED}

AA: Arachidonic Acid; ALA: Alpha Linolenic Acid; EPA: Eicosapentaenoic Acid; GC-MS: Gas Chromatography-Mass Spectroscopy; GLA: Gamma Linolenic Acid; LA: Linoleic Acid; OA: Oleic Acid; OD: Optical Density; PUFA: Poly Unsturated Fatty Acid; RBC: Red Blood Cell; SBT: Hippophae rhamnoides and Hippophae salicifolia seed oil

\section{REFERENCES}

1. UpretyY, Asselin H, Boon EK, Yadav S, Shrestha KK. Indigenous use and bio-efficacy of medicinal plants in the Rasuwa District, Central Nepal. J. Ethnobiol. Ethnomed. 2010;6(1):1-10. https://doi.org/10.1186/1746-4269-6-3; PMid:20102631 PMCid:PMC2823594.

2. Suryakumar G, Gupta A. Medicinal and therapeutic potential of Sea buckthorn (Hippophae rhamnoides L.). J. Ethnopharmacol. 2011;138(2):268-78. https://doi. org/10.1016/j.jep.2011.09.024; PMid:21963559.

3. Basu M, Prasad R, Jayamurthy P, Pal K, Arumughan, C Sawhney RC. Antiatherogenic effects of seabuckthorn (Hippophaea rhamnoides) seed oil Phytomed. 2007;14(11):770-7. https://doi.org/10.1016/j.phymed.2007.03.018; PMid:17498939

4. Salem N, Wegher B, Mena P, Uauy R. Arachidonic and docosahexaenoic acids are biosynthesized from their 18-carbon precursors in human infants. Proceedings of the National Academy of Sciences of the United States of America. 1996;93(1):49-54. https://doi.org/10.1073/pnas.93.1.49; PMid:8552667 


\section{PMCid:PMC40176.}

5. James MJ, Gibson RA, Cleland LG. Dietary polyunsaturated fatty acids and inflammatory mediator production. The American journal of clinical nutrition. 2000;71(1):343s-348s.PMid:10617994.

6. Carrillo Pérez C, Cavia Camarero MD, Alonso de la Torre S. Role of oleic acid in immune system; mechanism of action; a review. Nutrición Hospitalaria, 2012, v. 27, n. 4 (julio-agosto), p. 978-990. 2012.

7. Wolfe MM, Lichtenstein DR, Singh G. Gastrointestinal toxicity of nonsteroida anti-inflammatory drugs. N. Engl. J. Med. 1999;340(24):1888-99. https://doi. org/10.1056/NEJM199906173402407; PMid:10369853.

8. Langman MJ, Weil J, Wainwright P, Lawson DH, Rawlins MD, Logan RF, et al. Risks of bleeding peptic ulcer associated with individual non-steroidal antiinflammatory drugs. Lancet. 1994;343(8905):1075-8. https://doi.org/10.1016/ S0140-6736(94)90185-6.

9. Hossain MM, Ahamed SK, Dewan SM, Hassan MM, Istiaq MM, A Islam, et al. In vivo antipyretic, antiemetic, in vitro membrane stabilization, antimicrobial, and cytotoxic activities of different extracts from Spilanthes paniculata leaves. Bio. Res. 2014:47(1):45. https://doi.org/10.1186/0717-6287-47-45; PMid:25299748 PMCid:PMC4177068

10. Perianayagam JB, Sharma SK, Pillai KK. Anti-inflammatory activity of Trichodesma indicum root extract in experimental animals. J. Ethnopharmacol. 2006;104(3):410-4. https://doi.org/10.1016/j.jep.2005.08.077; PMid:16303271.

11. Okoli CO, Akah PA, Nwafor SV, Anisiobi , IN Ibegbunam, Erojikwe O, et al. Anti-inflammatory activity of hexane leaf extract of Aspilia Africana. J. Ethnopharmacol. 2007;109(2):219-25. https://doi.org/10.1016/j.jep.2006.07.037 PMid:16950582.

12. Opie EL. On the relation of necrosis and inflammation to denaturation of proteins. J Exp Med. 1962:115(3):597. https://doi.org/10.1084/jem.115.3.597 PMid:14482110 PMCid:PMC2137504.

13. Saso L, Valentini G, Casini ML, Mattei E, Braghiroli L, Mazzanti G, et al. Inhibition of protein denaturation by fatty acid, bile salts and other natural substances: A new hypothesis for mechanism of action of fish oil in Rheumatic Disease. Jpn J Pharmacol. 1999;79(1):89-99. https://doi.org/10.1254/jjp.79.89; PMid:10082322

14. Sabir SM, Maqsood H, Hayat I, Khan MQ, Khaliq A. Elemental and nutritional analysis of sea buckthorn (Hippophae rhamnoides ssp. turkestanica) Berries of Pakistani origin. J. Med. Food. 2005; 8(4):518-22. https://doi.org/10.1089/ jmf.2005.8.518; PMid:16379565

15. Shinde UA, Phadke AS, Nair AM, Mungantiwar AA, Dikshit VJ, Saraf MN. Membrane stabilization activity- a possible mechanism of action for the antiinflammatory activity of Cedrus deodara wood oil. Fitoterapia. 1989;70(3):251-7. https://doi.org/10.1016/S0367-326X(99)00030-1.

16. Nargund LV, Redd GR, Hariprasad V. Inhibition of albumin denaturation and anti-inflammatory activity of acetamido [(phenyl-4'-yl)-oxymethyl)]2-(p-substituted phenylamino)-1,2,4-triazoles and -1,3,4-thiadiazoles. Indian J Exp Biol 1993;31(4):395-6. PMid:8359842.

17. Yang B, Kallio HP. 2005. Lipophilic components of Seabuckthorn (Hippophae rhamnoides L.) seeds and berries. In: Singh, V. (Ed.), Seabuckthorn (Hippophae L.): A multipurpose Wonder Plant, vol. 2. Daya Publishing House, New Delhi, India, pp. 70-97.

18. Calder PC. Polyunsaturated fatty acids and inflammatory processes: New twists in an old tale. Biochimie. 2009;91(6):791-5. https://doi.org/10.1016/j.biochi.2009.01.008; PMid:19455748.

19. Calder PC, Albers R, JM Antoine, S Blum, R Bourdet-Sicard, GA Ferns, et al. Inflammatory disease processes and interactions with nutrition. Br J Nutr 2009;101(S1):S1-45. https://doi.org/10.1017/S0007114509377867; https://doi org/10.1017/S0007114508076228; https://doi.org/10.1017/S0007114509289070; PMid: 19586558.

20. Schmitz G, Ecker J. The opposing effects of n-3 and n-6 fatty acids. Prog Lipid Res. 2008;47(2):147-55. https://doi.org/10.1016/j.plipres.2007.12.004 PMid:18198131

21. Dubois, V., Breton, S., Linder, M., Fanni, J. Parmentier, M. 2007. Fatty acid profiles of 80 vegetable oils with regard to their nutritional potential. Eur. J. Lipid Sci. Tech.109(7):710-32. https://doi.org/10.1002/ejlt.200700040.

22. Dulf, F. V. 2012. Fatty acids in berry lipids of six sea buckthorn (Hippophae rhamnoides L., subspecies carpatica) cultivars grown in Romania. Chem. Cent. J. 6(1):106. https://doi.org/10.1186/1752-153X-6-106; PMid:22995716 PMCid:PMC3505179.

23. Medzhitov R. Origin and physiological roles of inflammation. Nature. 2008;454(7203):428-35. https://doi.org/10.1038/nature07201; PMid:18650913.

24. Ashley NT, Weil ZM, Nelson RJ. Inflammation: Mechanisms, Costs, and Natural Variation. Annu. Rev. Ecol. Evol. Syst. 2012;43:385-406. https://doi.org/10.1146/ annurev-ecolsys-040212-092530.

25. Ferrali M, Signorini C, Ciccoli L, Comporti M. Iron release and membrane damage in erythrocytes exposed to oxidizing agents, phenylhydrazine, divicine and isouramil. Biochem J. 1992;285(1):295-301. https://doi.org/10.1042/bj2850295; PMid:1637315 PMCid:PMC1132780.

26. Anderson R, Theron AJ, Feldman C. Membrane-stabilizing, anti-inflammatory interactions of macrolides with human neutrophils. Inflammation. 1996;20(6):693-705. https://doi.org/10.1007/BF01488805; PMid:8979156.

27. Borot F, Vieu DL, Faure G, Fritsch J, Colas J, Moriceau J, et al. Eicosanoid release is increased by membrane destabilization and CFTR inhibition in Calu-3 cells. PLoS One. 2009:4(10):e7116. https://doi.org/10.1371/journal. pone.0007116; PMid:19847291 PMCid:PMC2760709

28. Mounnissamy VM, Kavimani S, Balu V, Drlin QS. Evaluation of anti-inflammatory and membrane stabilizing properties of ethanol extract of Canjera rehedi. Iranian J Pharmacol Therapeut. 2008;6(2):235-7.

29. Richard D, Kefi K, Barbe U, Bausero P, Visioli F. Polyunsaturated fatty acids as antioxidants. Pharmacol Res. 2008;57(6):451-455. https://doi.org/10.1016/ . phrs.2008.05.002: PMid:18583147

30. Ting H, Hsu YW, Tsai CF, Lu FJ, Chou M, Chen WK. The in vitro and in vivo antioxidant properties of seabuckthorn (Hippophae rhamnoides L.) seed oil. Food Chem. 2011;125:652-9. https://doi.org/10.1016/j.foodchem.2010.09.057.

31. Gell PGH, B Benacerraf. Studies on hypersensitivity-II delayed hypersensitivity to denatured proteins in guinea pig. Immunology. 1959; 2: 64.PMid:13640681 PMCid:PMC1423907.

\section{GRAPHICAL ABSTRACT}

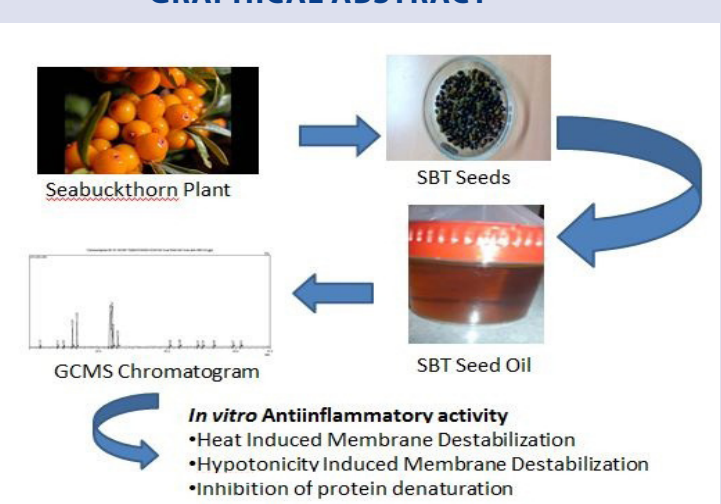

\section{SUMMARY}

- Seabuckthorn (HR and HS) Seed Oil is rich in PUFA as demonstrated by GC-MS analysis.

- HR and HR seed oil protect RBC membrane against destabilization induced by heat and hypotonicity.

- HR and HS seed oil also inhibit protein denaturation which is comparable to Aspirin.

- These activities may be attributed to presence of high OA and ALA in HR and HS seed oil.

\section{ABOUT AUTHOR}

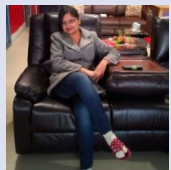

Suchita Dubey is an M. Pharm. (Pharmacology) with almost 4 years of experience in academics and Industry. She has authored 10 research and review articles in peer reviewed national and international journals. Her core area of research is Inflammation and Opthalmology. 


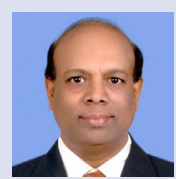

Dr. M.V. Ramana is Ph.D. in Pharmaceutics and has almost 35 years of experience as a researcher and academician. His expert areas are drug development and novel drug delivery systems

Dr. Anuradha Mishra is Ph.D. in Pharmacology and has around 11 years of experience in research and academics. Her core research areas are Neuropharmacology and Oncopharmacology.

Cite this article: Dubey S, Ramana MV, Mishra A. Comparison of Fatty Acid Profiling and RBC Membrane Stabilization Activity of Seabuckthorn (Hippophae rhamnoides and Hippophae salicifolia) Seed Oil. Pharmacogn J. 2017:9(3):329-35. 